Journal of Business and Social Review in Emerging Economies ISSN: 2519-089X (E): 2519-0326

Volume 6: No. 1, March 2020 Journal homepage: www.publishing.globalcsrc.org/jbsee

\title{
Credit Risk in Asset Based Sukuk ${ }^{1}$ Areeba Khan, ${ }^{2}$ Sohail Saeed, ${ }^{3}$ Zulaiha A. Zubair, ${ }^{4}$ Iffat Hussain \\ ${ }^{1}$ Department of Management Sciences, The Islamia University of Bahawalpur, Pakistan \\ ${ }^{2}$ Department of Commerce, The Islamia University of Bahawalpur, Pakistan \\ ${ }^{3}$ Federal University Dutsinma,Katsina State Nigeria \\ ${ }^{4}$ The Islamia University of Bahawalpur, Pakistan
}

\begin{tabular}{l} 
ARTICLE DETAILS \\
\hline History \\
Revised format: February 2020 \\
Available Online: March 2020 \\
\hline Keywords \\
Sukuk, Special Purpose Vehicle \\
(SPV), Credit Risk, Ijara, Asset \\
Based, Issuance, Asset Backed, \\
Government of Pakistan \\
(GOP), Musharaka
\end{tabular}

JEL Classification:

E51, D88, G32, G19

\begin{abstract}
Purpose: This study is intended to find the credit risks in Asset based Sukuk. The risk of default of Sukuk is called a credit risk. Various risks regarding the Sukuk have been identified.
\end{abstract}

Limitations/Implications: The study focuses on the Sukuk issuances of Pakistan. In the current scenario of Pakistan and the need to finance the Diameer Bahasha Dam and Naya Pakistan Housing Program Sukuk is an attractive option. Pakistan has yet not overcome the energy shortfall, and the environment of Pakistan has been effected by the global changes so for the adoption of cleantech green Sukuk is a most appropriate option.

Originality/ Value: There has been a significant contribution of Pakistan in the issuance of Sukuk activity and there are Sukuk defaults too. Yet, in Pakistan the research on Sukuk has not been done. So this study shall add to the literature in Pakistan.

(c) 2020 The authors, under a Creative Commons AttributionNonCommercial 4.0

Corresponding author's email address: areeba.khan@iub.edu.pk

Recommended citation: Khan, A., Saeed, S., Zubair, Z.A., Hussain, I. (2020). Credit Risk in Asset Based Sukuk. Journal of Business and Social Review in Emerging Economies, 6(1), 239-260

DOI: $10.26710 /$ jbsee.v6i1.1043

\section{Introduction}

The first Sukuk issuance was done by "Shell" a conventional firm of Malaysia becoming the pioneer of Sukuk issuances the issue was of 125 million Malaysian Ringit it was a Bai Bitheman Ajil (BBA) (Ahmad, Rahim, \& Sukuk, 2013). Later Sukuk were well recognized by the whole world but it showed less growth until 2010 as can be seen in the International Islamic Financial Market report of Sukuk of 2017.

In the year 2017 the biggest issuances were made by the Government of Saudi Arabia Sovereign Sukuk of USD 9 billion, The Investment Corporation of Dubai USD 1 billion Quasi Sovereign Sukuk and Sukuk of US 150 million by the African corporation in Nigeria. In the recent 5 years the total issuances in Pakistan were of Pakistani rupee value 1383.696, and there were seven issuances from all sovereign, quasi sovereign and corporate isuances. In Pakistan there were most number of issuances were made up of Musharaka, however in the monetary terms there were more issuances were of Ijara Sukuk. The given reason is that Musharaka Sukuk were issued by corporations who do not accumulate 
In Islamic finances basically usury (riba) is categorically prohibited as well as, speculation, gambling (maisir) and ambiguity (gharar) are prohibited (Hussain \& Turk-Ariss, 2015). Since 50 years Islamic Financial and business institutions have developed such investment solutions that are compliant with Shariah as well as the principles of commerce and finance and a continuous $17.5 \%$ annual growth has been witnessed in this sector (Jakhura, 2016). And the emergence of Sukuk has added to this growth and today $90 \%$ of the Islamic Finance consists on Sukuk (Ahmad et al., 2013). As Sukuk offer 14 type of structures that are permissible by Shariah which are a great attraction not only for the Muslim investor but also for the non-Muslim investors as well as conventional business and banking institutions.

\subsection{Etymology}

In Arabic Sak means any document or a cheque and Sukuk is plural of Sak (S.R. Vishwanath, 2009), Sukuk is a Islamic bond (financial instrument) alternative to conventional bond that is asset backed and is being used by governments, Islamic banks \& institutions, sovereigns, and conventional companies (Rezaei, 2013). The more clear definition of Sukuk is presented by Accounting and Auditing Organization of Islamic Financial Institutions (AAOIFI) in its legal standards:

"Certificates with the same value which after accomplishment of the underwriting process; it represents the nominal amount paid by the buyer to issuer and the holder will be the owner or a set of assets, benefits of the asset or beneficiaries of an activity or a specific investment project".

\subsection{The Global Sukuk Issuances}

Sukuk are not specific to the Islamic corporation, sovereign or investor. But more conventional companies, non Muslim investors, European, African sovereign have also issued and invested their finances in these securities. The countries of Asia and Fareast have issued 90.2 percent of the Sukuk, GCC and Middle East companies have $4.3 \%$ contribution, African countries have $4.5 \%$ and European and other countries have $0.95 \%$ in the global short term Sukuk issuances.

Malaysia has maximum percentage of Sukuk issuances as at $31^{\text {st }}$ December 2017 by $51.09 \%$, after this Saudi Arabia adds to this percentage by $18.729 \%$ and then Indonesia has part of $10.660 \%$ so the list goes on and Pakistan has $1.785 \%$ of Sukuk issuance outstanding with the value of 7762 million US dollars. There was a huge rise in the Sukuk activity in 2017 as compared to 2016. The major contributors to this rise were Saudi Sukuk issuances and also the green Sukuk issued by Malaysia. This has become the promising mode of finance that has been contributing to Islamic finance. 
Table 1:Total Global Short Term Sukuk Issuances from (January 2001 to December 2017)

\begin{tabular}{|c|c|c|c|}
\hline ASIA \& FAR EAST & $\begin{array}{l}\text { ASIA \& FAR EAST } \\
\text { Number of Issuances }\end{array}$ & Amount USD Millions & \%of total value \\
\hline Bangladesh & 4 & 37 & $0.010 \%$ \\
\hline Brunei Darussalam & 136 & 8571 & $2.33 \%$ \\
\hline Indonesia & 45 & 4085 & $1.11 \%$ \\
\hline Malaysia & 2598 & 318420 & $86.67 \%$ \\
\hline $\begin{array}{l}\text { Pakistan } \\
\end{array}$ & 8 & 141 & $0.04 \%$ \\
\hline Singapore & 3 & 221 & $0.06 \%$ \\
\hline Total & 2794 & 331475 & $90.2 \%$ \\
\hline GCC \& MIDDLE EAST & Number of Issues & Amount USD Millions & \%of total value \\
\hline Bahrain & 319 & 14,098 & $3.84 \%$ \\
\hline Oman & 1 & 130 & $0.04 \%$ \\
\hline Saudi Arabia & 6 & 1301 & $0.35 \%$ \\
\hline United Arab Emirates & 1 & 100 & $0.03 \%$ \\
\hline Yemen & 1 & 234 & $0.06 \%$ \\
\hline Total & 328 & 15862 & $4.3 \%$ \\
\hline Africa & Number of Issues & Amount USD Millions & \%of total value \\
\hline Gambia & 210 & 136 & $0.04 \%$ \\
\hline Sudan & 16 & 16,435 & $4.47 \%$ \\
\hline Total & 226 & 16571 & $4.5 \%$ \\
\hline Europe and others & Number of Issues & Amount USD Millions & \%of total value \\
\hline Turkey & 101 & 3501 & 0.95 \\
\hline Total & 101 & 3501 & 0.95 \\
\hline Grand total & 3499 & 367,410 & $100 \%$ \\
\hline
\end{tabular}

\section{Source: IIFM database 2018}

\subsection{Sukuk in Pakistan}

In Pakistan the first Sukuk issuance was made in the 2005 and that was a sovereign issuance made by the Government of Pakistan and the trend started, the corporates and Quasi sovereign Sukuk were being issued and then there were two defaults reported in 2009 of corporate Sukuk issuances in Pakistan namely New Allied electronics companies of \$ 16.4 million and Maple leaf was defaulted on PKR 8 billion Sukuk. There were 15 Sukuk default cases from all over the world. And reasons for these defaults were well explored by the researchers of different countries. And also the risks of the Sukuk regarding various structures of Sukuk as well as the risks exposed to the parties involved in the Sukuk agreement were also explored. Pakistani government has been Issuing Sukuk for the liquidity management and to cater the fiscal deficit.

\subsection{Significance of Sukuk in Pakistan}

As Sukuk is the product that belongs to the Islamic Finance so it is mandatory to discuss about Islamic finance in in brief in the context of Pakistan. As conventional banking is driven by the interest that is named as Riba and categorically prohibited in Islam. The first 
Sukuk in Pakistan was issued by Government of Pakistan in 2005 which was a sovereign and international Sukuk that was listed on Luxemberg Stock Exchange, worth of \$600, rated B+ by Standard and Poor, on Ijara bases, offering semi-annual floating rate of LIBOR+220 basis points gaining a huge response of 1.2 billion US dollars. And later in 2006 the domestic Sukuk were issued. There were more issues in the years 2009 to 2012 (IIFM, 2014).

\begin{tabular}{|c|c|c|c|c|c|c|c|}
\hline Issue date & Amount & $\begin{array}{l}\text { amount in } \\
\text { PKR } \\
\text { (billions) }\end{array}$ & Tenor & Sukuk type & Issuer & SPV name & $\begin{array}{l}\text { Dollar price } \\
\text { in Pakistan in } \\
\text { the date of } \\
\text { issue }\end{array}$ \\
\hline Dec, 5,2017 & $\$ 1$ billion & 104.03 & 5 years & Ijara & $\begin{array}{l}\text { Government of Pakistan } \\
2022\end{array}$ & $\begin{array}{l}\text { The Third Party } \\
\text { International Sukuk Co. } \\
\text { LTD }\end{array}$ & 104.030 \\
\hline Jul, 14, 2017 & $\begin{array}{ll}\text { PKR } & 5 \\
\text { billion } & \end{array}$ & 5 & $\begin{array}{l}10 \\
\text { years }\end{array}$ & Ijara & $\begin{array}{l}\text { Dubai Islamic Bank } \\
\text { Pakistan } 2027\end{array}$ & $\begin{array}{l}\text { Dubai Islamic Bank } \\
\text { Pakistan (DIBPL) }\end{array}$ & \\
\hline Oct, 13,2016 & $\$ 1$ billion & 103.745 & 5 years & Musharka & $\begin{array}{l}\text { Government of Pakistan } \\
2021\end{array}$ & $\begin{array}{l}\text { The Third Party } \\
\text { International Sukuk Co. } \\
\text { LTD }\end{array}$ & 103.745 \\
\hline Apr, 21, 2016 & $\begin{array}{l}\text { PKR100 } \\
\end{array}$ & 100 & 10 & Arrangers & $\begin{array}{l}\text { Neelum } \\
\end{array}$ & $\begin{array}{l}\text { Neelum Jhelum Hydro } \\
\text { Power } \quad \text { (NJHPC) }\end{array}$ & \\
\hline
\end{tabular}

TABLe 1 Sukuk IsSued in RECEnt 5 Years in Pakistan Source: www.Sukuk.com

Until 2009 the number of Sukuk issued was 31 and the total amount of Sukuk were 1627 million dollars that was $1.6 \%$ of total Sukuk market (Ab Majid, Shahimi, \& Hafizuddin Syah Bangaan Abdullah, 2011). During recent 5 years government of Pakistan have issued worth billion Sukuk, and Water And Power Development Authority (WAPDA) has issued Sukuk to finance huge projects. Governments or sovereign issue Sukuk for management of the fiscal deficit (Kamarudin, Kamaluddin, Manan, \& Ghani, 2014a).

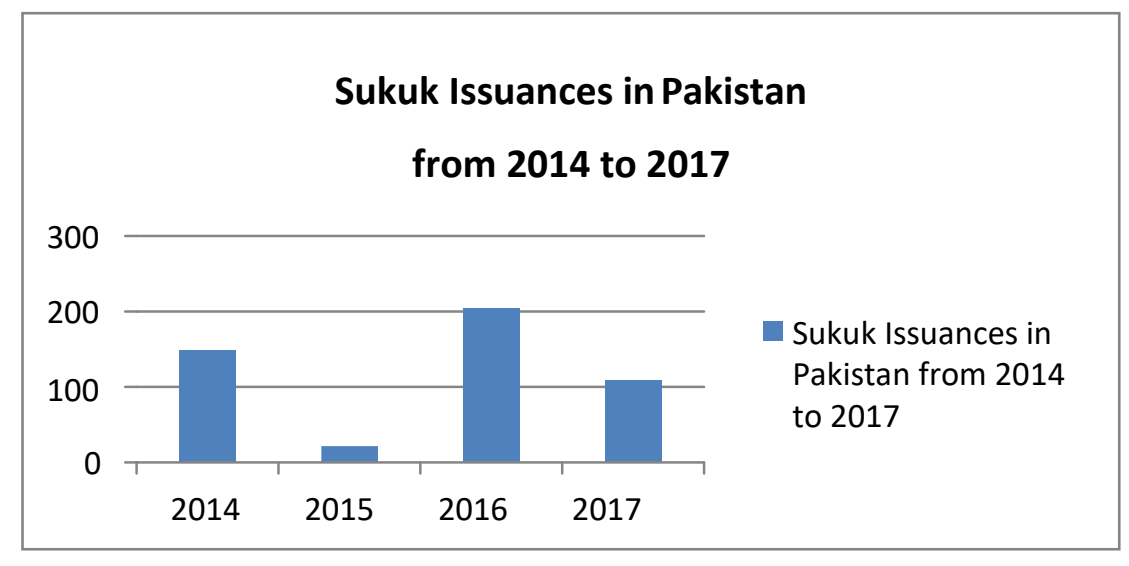

Source: Figure 1 Sukuk issuance in Pakistan (Sukuk.com)

\subsection{Secondary Market of Sukuk in Pakistan}

As there is more demand of Sukuk in domestic market of Pakistan yet the supply is less frequent as compared to the demand by the investor due to the reason that Sukuk offer an attractive avenue to the Islamic financial institutions. So the Sukuk holders usually keep Sukuk until the maturity for this reason the secondary market of Sukuk is almost inactive. 


\begin{tabular}{|ll|ll|}
\hline 1. & Income is generated from assets & 1. & Income is derived from debt instrument \\
\hline 2. & Return is expected & 2. & Return is interest and pre-determined \\
\hline 3. & $\begin{array}{l}\text { Negotiability is restricted to specific types of } \\
\text { Sukuk }\end{array}$ & 3. & Negotiable financial paper \\
\hline 4. & Sukuk issue is a seller of assets & 4. & Bond issuer is a borrower \\
\hline 5. & Sukuk holder is an owner of assets & 5. & Bond holder is a lender \\
\hline 6. & Seller-Buyer relationship & 6. & Lender-borrower relationship \\
\hline 7. & Business risk-return relationship & 7. & $\begin{array}{l}\text { Issuer guarantees the payment of face value } \\
\text { and periodic interest }\end{array}$ \\
\hline 8. & Major risk lays with underlying assets & 8. Major risk is with issuer - credit risk \\
\hline 9. & Return is expected from the underlyingassets & 9. Interest payment is an obligation \\
\hline $\begin{array}{l}\text { 10. } \\
\text { Return of investor's capital cannot be } \\
\text { guaranteed }\end{array}$ & $\begin{array}{l}\text { 10. Issuer is obligated to return investor's capital } \\
\text { (face value) }\end{array}$ \\
\hline
\end{tabular}

\subsection{Sukuk Structures}

Sukuk are basically divided on four bases that are asset based, equity based, debt based agency based as well as hybrid structure (involves 2 or more underlying contracts). And the belonging Sukuk contracts are given below
1) Debt based structure: Murabaha Sukuk and Istisna'a Sukuk
2) Equity based structure: Musharaka Sukuk and Mudaraba Sukuk
3) Asset Based structure: Ijara Sukuk and

Manfa Sukuk; and finally Agency based structure:

the Wakala Sukuk(Alswaidan et al., 2017)

\subsection{Asset based v/s Asset Backed Sukuk}

Numbers of types of Sukuk are identified by many researchers. Basically there are two type of Sukuk that are asset based in which Sukuk holders get beneficial ownership of asset and have recourse to the originator and asset back in which the holders of Sukuk become true owners of the asset for this reason they do not have recourse to the originator (Afshar, 2013).

\section{TABle 2: CATEgories OF SUKUK}

\begin{tabular}{|c|c|c|}
\hline Categories & Asset based & Asset backed \\
\hline Source of Payment & $\begin{array}{l}\text { The source of payment comes from } \\
\text { originator/obligor's cash flows. }\end{array}$ & $\begin{array}{l}\text { The source of payment comes } \\
\text { from the revenue generated by } \\
\text { underlying } \\
\text { Asset. }\end{array}$ \\
\hline $\begin{array}{l}\text { Presentation/disclo } \\
\text { sure of the asset }\end{array}$ & $\begin{array}{l}\text { The asset stays on the balance sheet of } \\
\text { originator/obligor }\end{array}$ & $\begin{array}{l}\text { The asset is separated from the } \\
\text { originator's book. }\end{array}$ \\
\hline Type of Sukuk holders' & $\begin{array}{l}\text { Beneficial ownership with no right to } \\
\text { dispose }\end{array}$ & Legal ownership with right \\
\hline Ownership & the asset & To dispose of asset. \\
\hline Recourse & $\begin{array}{l}\text { Purchase undertaking at par from obligor is } \\
\text { the ultimate recourse. The recourse is only } \\
\text { to obligor and not the asset. }\end{array}$ & $\begin{array}{l}\text { Sukuk holders only have recourse } \\
\text { to asset thus asset plays genuine } \\
\text { role in defaults. }\end{array}$ \\
\hline
\end{tabular}


So in this regard Islamic Financial securities have provided not only Muslims with the Shariah compliant numerous investment tools rather it has gained the attention of conventional as well as non Muslim investors to invest in them in order to make profit and also diverse their investment portfolio. A $17.5 \%$ consistent and continual rise in the growth of Islamic fiancé has been witnessed in in Islamic banking and finance. Debt markets however provide an efficient liquidity management system(Jakhura, 2016)

\subsection{Risk mitigation and risk management in Islam; how Sukuk contribute to mitigate risk Parties}

In the view of Islam a risk can never be avoided however mitigation is recommended and permitted through taking different remedies and precautions and this is an aim in Islamic financial securities (Alswaidan et al., 2017). The Islamic finance has provided a way through which risk can be mitigated and managed that is "takaful". Takaful allows to distribute the loss in the parties of the policy holders rather it is fully transferred to the insurance company that has been practiced in the conventional finance

(Mohammed Imad Ali, n.d.). Sukuk have also been suggested as the tools for mitigation of risk by (Alswaidan et al., 2017).

\subsection{The Global Perspective of Sukuk}

Since 1970 Islamic finance started to flourish and Muslims were far from western type financial markets because of involvement of interest (Riba) and non-Islamic practices, with the time modernization in Islamic finance took place and in 1990 first Sukuk were issued. Sukuk paved a way for Muslim investors and corporates for liquidation, mobilization, risk mitigation, capital, and secondary and primary market creation (Alsayyed \& Farhan, 2010 b). In the terms or US dollars sovereign issues are maximum is percent that is 81 , there are 9\% Quasi- Sovereign issuances, 9\% corporate issuances and 1\% financial institutions issuances (Market, 2018).

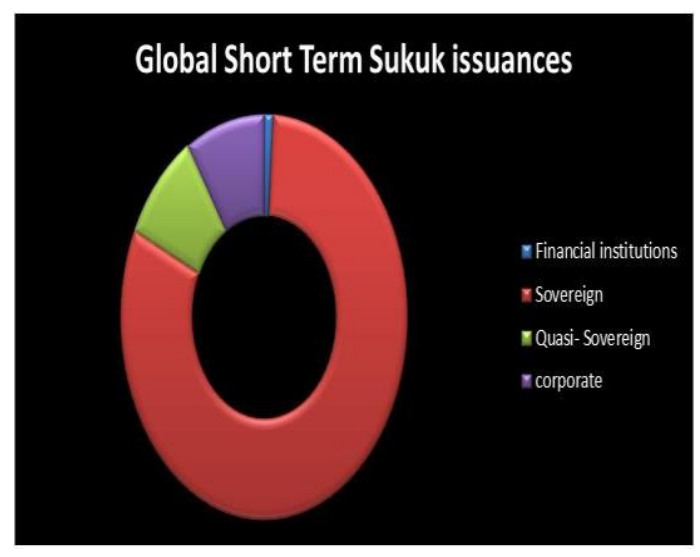

TABLE 3 SHORT TERM SUKUK

2.7 Global Short term Sukuk issuances from 2001 to 2017 (on the issuer bases)

While taking an overview of the market (Hussain \& Turk-Ariss, 2015) have disclosed that a conventional company of Malaysia was pioneer of the Sukuk issuance in 1990, since 
Malaysia remains dominant in issuing Sukuk however Muslim and other than Muslim countries as well as conventional companies issued Sukuk to cater their need of finances and for diversification of their portfolio. The Sukuk has provided the investors with a big number of options for the investment and diversification of portfolio. Emergence of Sukuk have also contributed in the growth Islamic Financial institutions (Ayub,

2018) with a variety of structures like Ijara, Musharaka, Mudaraba, Salam, Bai Bithaman

TABLE 4 TOTAL GLobal SUKUK ISSUANCES FROM JANUARY 2001 TO

DECEMBER 2017

Ajil and Hybrid Sukuk to be adopted by the issuer as it is favorable to them.
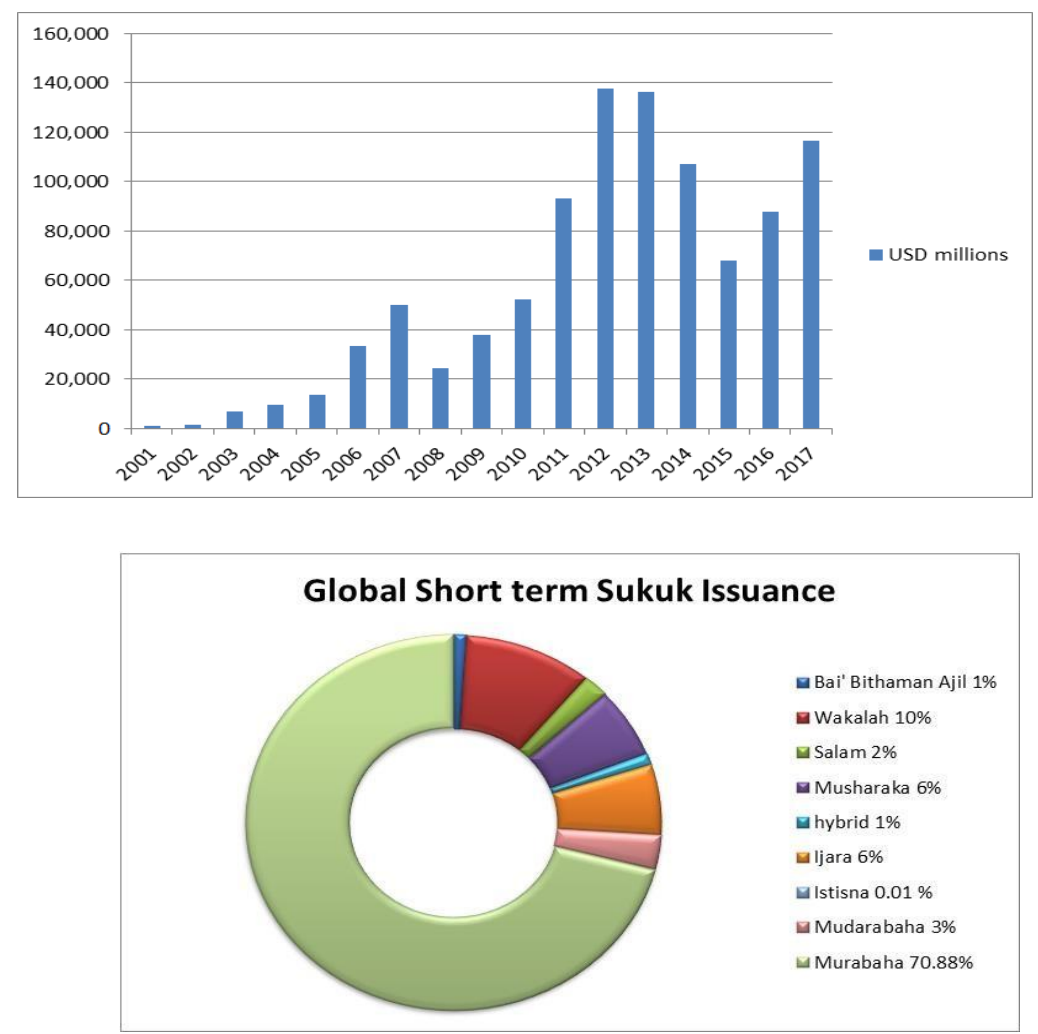

TABLE 5 STRUCTURE WISE BREAKDOWN OF GLOBAL SUKUK ISSUANCES

Source: IIFM (International Islamic Financial Market) Sukuk Database 2018

Table 6 Country WiSe Breakdown of SuKuk OUtSTanding as OF 31ST December 2017

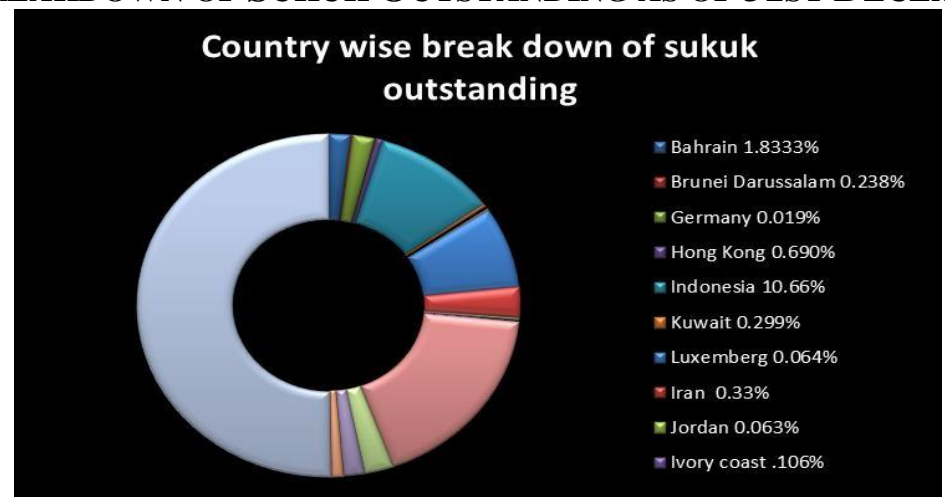

Source IIFM (International Islamic Financial Market) Sukuk Database 2018

Credit Risk embedded in Sukuk contract and securitization (Sukukization) 
The Sukuk holders have limited recourse over asset because they have beneficial ownership of asset so in the case of any default in the obligations the ownership of the asset is not transferred to the Sukuk holders; neither is it transferred to the Sukuk holders nor is it transferred to the creditors of the originator. Here one thing is revealed that in the history of asset based Sukuk only in the US issued by ECP (East Cameron Partners) Sukuk default in

\begin{tabular}{|c|c|c|c|}
\hline Year & Corporate & Sovereign & Quasi-Sovereign \\
\hline 2006 & 7.2 & 0 & 92.8 \\
\hline 2007 & 5.5 & 0 & 44.5 \\
\hline 2008 & 48.6 & 14 & 37.4 \\
\hline 2009 & 43.3 & 29 & 27.7 \\
\hline 2010 & 27.3 & 55.6 & 17.1 \\
\hline 2011 & 15.6 & 72.7 & 11.4 \\
\hline 2012 & 11.5 & 79.3 & 9.2 \\
\hline 2013 & 10.7 & 78.5 & 10.8 \\
\hline 2014 & 9.9 & 79.3 & 10.8 \\
\hline
\end{tabular}

which the asset was transferred to the investors.

\section{Source: IIFM SUKUK REPORT 2014}

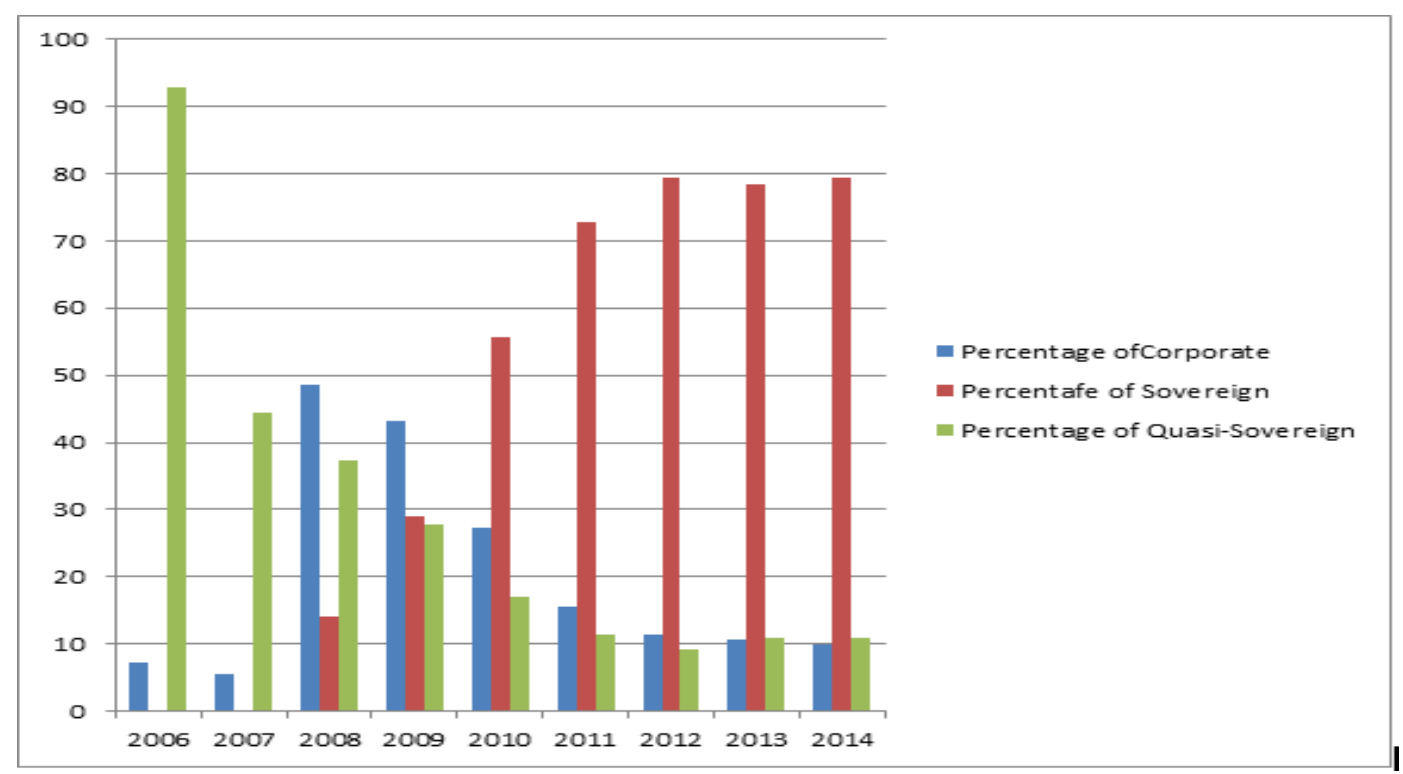

TABLE 7 ENTITY AND YEAR WISE BREAK DOWN OF SUKUK IN PAKISTAN (CUMULATIVE AS OF END YEAR IN PERCENTAGE)

\subsection{Sukuk rating}

Compliance with Shariah rules and standards is most important for the issuance of Sukuk this discriminates the Islamic Capital Market instruments from that of conventional debt securities. The regulatory framework to issue the Islamic Securities requires the appointment of Shariah advisors to advise on all aspects of Islamic securities and to ensure the compliance with applicable Shariah principles and relevant rulings and regulations 

made by Securities Commission Shariah advisory council (Haron, 2012)

\subsection{AAOIFI's Adjudication on Sukuk}

The chairman of Accounting and Auditing Organization for Islamic Financial Institution Shaikh Muhammad Taqi Usmani declared that almost $85 \%$ of the issued Sukuk were not in compliance with Shariah standards because majority of the Sukuk were asset based instead of asset backed Sukuk.

\subsection{Sukuk Defaults}

Everything comes up with its pros and cons so do Sukuk. It was misapprehend until Sukuk defaults took place in 2009 that the Sukuk are risk free securities because of its compliance with sharaiah rules (Kamarudin et al., 2014a). There were 15 Sukuk defaults befallen in the year 2009 the year following global financial year 2008 and the year 2009 was verbalized as the "default year(Kamarudin et al., 2014a).

\subsection{Sukuk Defaults in 2009}

\begin{tabular}{|l|c|c|}
\hline \multicolumn{1}{|c|}{ Company } & Country \\
\hline d Group's Golden Belt & $\$ 650$ & Saudi Arabia \\
\hline East Cameron Gas & $\$ 165.6$ & USA \\
\hline vestment Dar Company & $\$ 100$ & Kuwait \\
\hline ied Electronics Industries & $\$ 16.4 \mathrm{M}$ & Pakistan \\
\hline Oxbridge Height & PKR 8 B & Pakistan \\
\hline Hartaplus, Ingress & $\$ 2.82 \mathrm{M}$ & Malaysia \\
\hline Oilcorp Bhd & $\$ 7.2 \mathrm{M}$ & Malaysia \\
\hline SB Ship management & $\mathbf{R M 4 0 ~ m}$ & Malaysia \\
\hline
\end{tabular}

\begin{tabular}{|l|l|l|}
\hline Tracoma Holdings & RM 100 m & Malaysia \\
\hline -Trex Corporation & & \\
\hline glotechs HOLDING & RM 60 m & Malaysia \\
\hline traight A's portfolio & RM 50 M & Malaysia \\
\hline mn International Tuna Port & RM 200 M & Malaysia \\
\hline
\end{tabular}

\section{Source: Business Islamica}

\section{Megazine 2010}

\section{Risks of Sukuk}

The risk of the Sukuk arises as the current ratio of an issuer declines in this scenario the issuer may default on the periodical payments of the Sukuk. So it is claimed that the Sukuk are 

exposed to such more risks that the conventional bonds are not exposed to (Alswaidan et al., 2017).

\subsection{Risk identification of Sukuk in Pakistan}

Islamic securities offer an attractive investment opportunities to both conventional and Islamic Financial institutions, and are welcomed globally. So in Pakistan in 2005 the first Sukuk was issued and since then the trend to issue Sukuk has been flourishing. In the year 2009 there were 2 corporate defaults occurred in Pakistan. And in the global Sukuk industry there were 15 defaults reported(Mohammad Khnifer, n.d.) out of which 2 Sukuk of Pakistan were defaulted. The Quetta textile Mills Limited Sukuk were found from the credit rating company site JCR-VIS (Exhibit, 2012).

Fig 2. Interest Rates for lending in comparison with LIBOR over

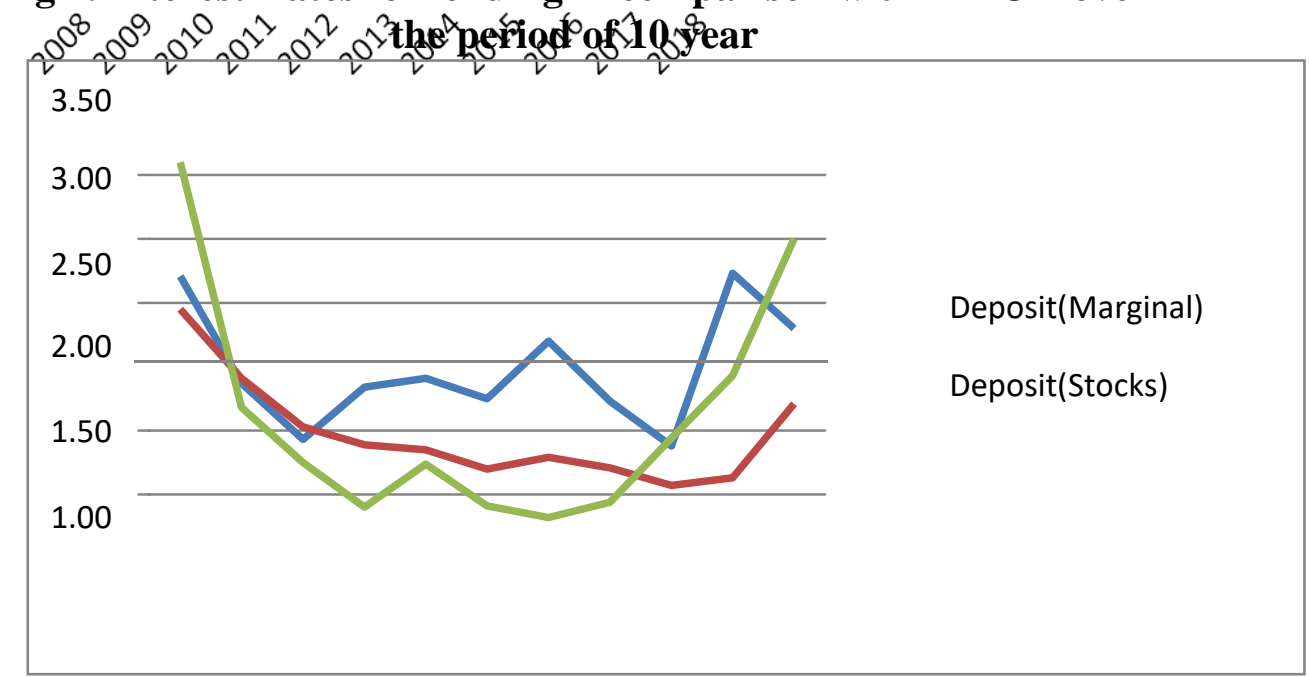

Fig. 3 Interest Rates for deposit in comparison with LIBOR over the period of 10 years

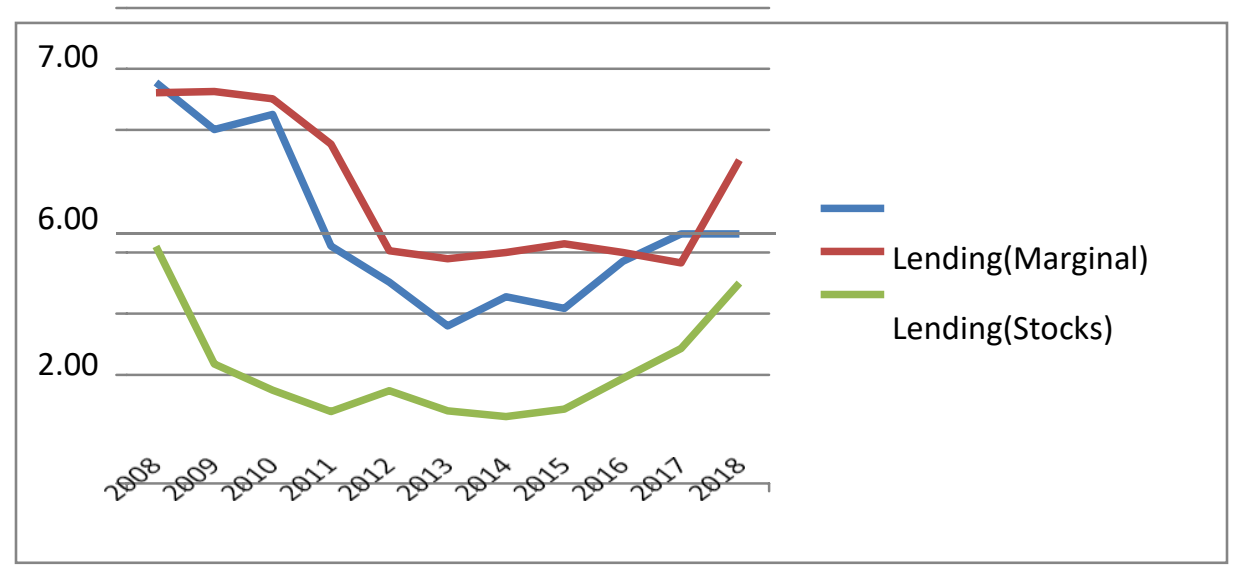

Source: GOP data From State Bank of Pakistan (www.sbp.org.pk) 
Fig. 4 The risk exposed to various Sukuk stake holders

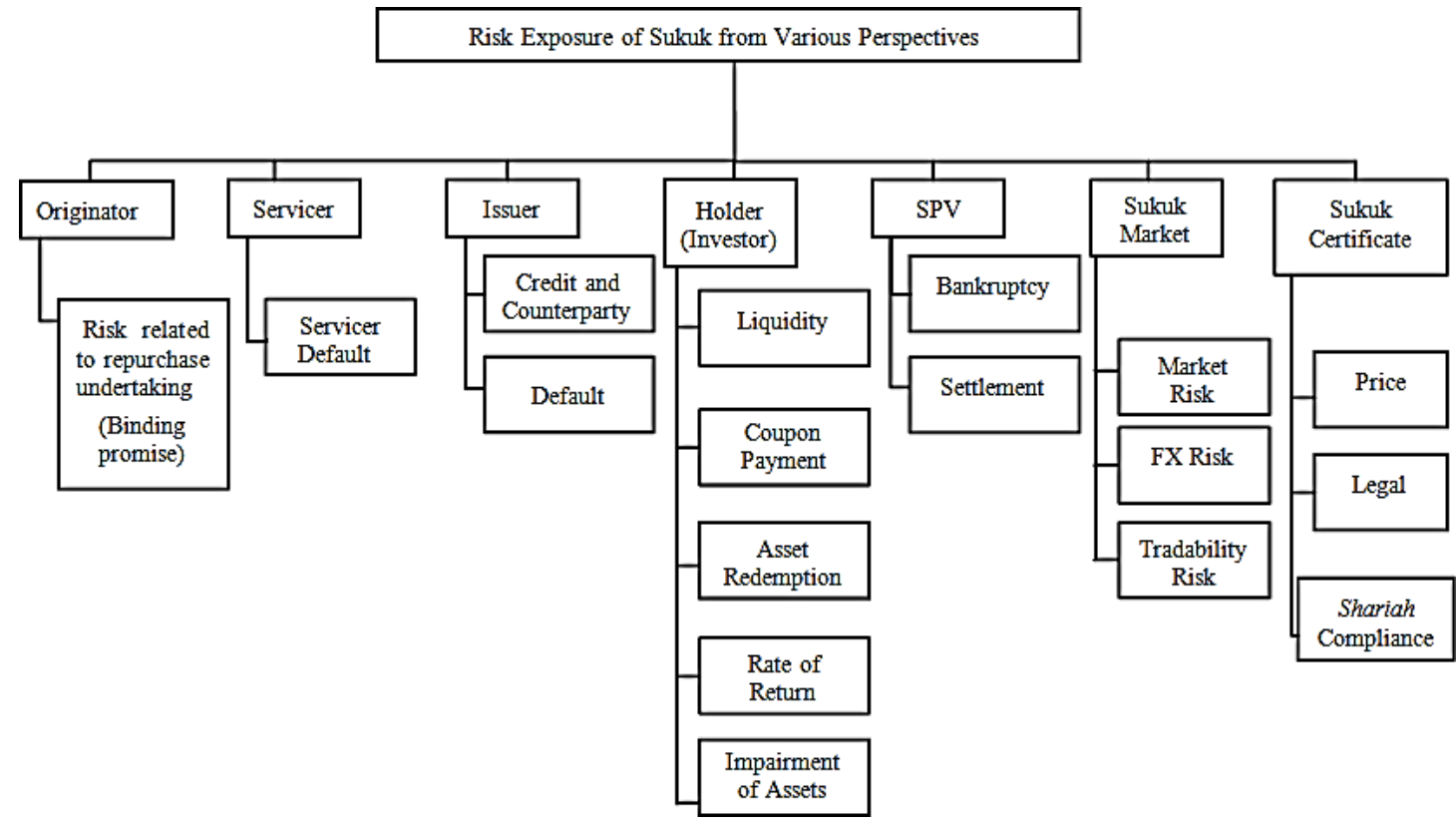

Sources: Created by Islamic Financial Services Board (IFSB) 7 (2005)

\subsection{Originator risk related to repurchase}

There is always a phenomenon of over subscription and under subscription of a particular security exists in market when the security in a market is offered. In the scenario of Pakistan 39\% of the offerings are under-priced on average(Kayani \& Amjad, 2011).

But as we see the comparison of yields on bonds, T-bills and Sukuk then we can witness that the Sukuk has least yields as compared to others. Because of this the investors shall prefer to invest in other securities rather investing in Sukuk.

Source: Author's Own Calculations based on GOP data

\begin{tabular}{|c|c|c|l|r|r|r|c|}
\hline $\begin{array}{c}\text { Auction } \\
\text { No. }\end{array}$ & Auction Date & $\begin{array}{c}\text { Date of } \\
\text { Settlement }\end{array}$ & \multicolumn{1}{l|}{$\begin{array}{l}\text { Maturity } \\
\text { Date }\end{array}$} & $\begin{array}{c}\text { Target } \\
\text { Announced }\end{array}$ & $\begin{array}{c}\text { Amount } \\
\text { Offered }\end{array}$ & $\begin{array}{c}\text { Amount } \\
\text { Accepted }\end{array}$ & $\begin{array}{l}\text { Cut-off } \\
\text { Margin }\end{array}$ \\
\hline GIS-1 & 15-Sep-08 & 26-Sep-08 & 26-Sep-11 & $10,000.00$ & $9,522.50$ & $6,522.50$ & 45.00 \\
\hline GIS-2 & 20-Dec-08 & 29-Dec-08 & 29-Dec-11 & $10,000.00$ & $7,350.00$ & $6,000.00$ & 75.00 \\
\hline GIS-3 & 4-Mar-09 & 11-Mar-09 & 11-Mar-12 & $10,000.00$ & $21,425.00$ & $15,325.00$ & 0.00 \\
\hline GIS-4 & 5-Sep-09 & 17-Sep-09 & 17-Sep-12 & $10,000.00$ & $30,381.00$ & $14,396.00$ & $(5.00)$ \\
\hline GIS-5 & 8-Nov-10 & 15-Nov-10 & 15-Nov-13 & $40,000.00$ & $64,712.00$ & $51,837.00$ & 0.00 \\
\hline GIS-6 & 13-Dec-10 & 20-Dec-10 & 20-Dec-13 & $40,000.00$ & $57,754.00$ & $37,174.00$ & 0.00 \\
\hline GIS-7 & 1-Mar-11 & 7-Mar-11 & 7-Mar-14 & $45,000.00$ & $56,839.70$ & $47,539.70$ & 0.00 \\
\hline GIS-8 & 9-May-11 & 16-May-11 & 16-May-14 & $45,000.00$ & $51,253.70$ & $45,803.70$ & 0.00 \\
\hline GIS-9 & 20-Dec-11 & 26-Dec-11 & 26-Dec-14 & $50,000.00$ & $84,169.10$ & $70,269.10$ & 0.00 \\
\hline GIS-10 & 23-Feb-12 & 2-Mar-12 & 2-Mar-15 & $50,000.00$ & $55,723.90$ & $38,123.90$ & 0.00 \\
\hline GIS-11 & 23-Apr-12 & 30-Apr-12 & 30-Apr-15 & $25,000.00$ & $50,432.00$ & $29,632.00$ & 0.00 \\
\hline GIS-12 & 20-Jun-12 & 28-Jun-12 & 28-Jun-15 & $25,000.00$ & $57,965.80$ & $48,765.80$ & 0.00 \\
\hline GIS-13 & 11-Sep-12 & 18-Sep-12 & 18-Sep-15 & $45,000.00$ & $110,599.90$ & $47,017.80$ & $(25.00)$ \\
\hline GIS-14 & 26-Mar-13 & 28-Mar-13 & 28-Mar-16 & $43,000.00$ & $86,255.30$ & $43,018.00$ & $(30.00)$ \\
\hline GIS-15 & 20-Jun-14 & 25-Jun-14 & 25-Jun-17 & $49,500.00$ & $113,720.00$ & $49,537.00$ & $(200.00)$ \\
\hline GIS-16 & 15-Dec-15 & 18-Dec-15 & 18-Dec-18 & $100,000.00$ & $273,303.00$ & $117,723.00$ & $(50.00)$ \\
\hline & & TOTAL & & & $1,131,406.900$ & $668,684.500$ & \\
\hline
\end{tabular}




\subsection{Yields of Different Securities}

\begin{tabular}{|l|c|c|c|c|c|c|c|c|}
\hline GDP Growth Rate & $3.50 \%$ & $3.62 \%$ & $3.84 \%$ & $3.68 \%$ & $4.05 \%$ & $4.06 \%$ & $4.56 \%$ & $5.37 \%$ \\
\hline Sukuk Yield & $12.52 \%$ & $13.36 \%$ & $13.45 \%$ & $11.33 \%$ & $3.11 \%$ & $7.97 \%$ & $6.10 \%$ & $5.24 \%$ \\
\hline Bond Yield & $12.72 \%$ & $12.94 \%$ & $13.36 \%$ & $11.72 \%$ & $10.86 \%$ & $11.87 \%$ & $7.71 \%$ & $6.31 \%$ \\
\hline T-Bill Yield & $12.51 \%$ & $12.54 \%$ & $13.11 \%$ & $10.99 \%$ & $9.32 \%$ & $9.89 \%$ & $7.11 \%$ & $5.98 \%$ \\
\hline
\end{tabular}

TABle 9 Comparative Asset YieldS

Source: Author's Own Calculations based on GOP data From State Bank of Pakistan (www.sbp.org.pk)

When Sukuk yield is compared to the yields of other securities and GDP growth rate than all the securities have declining trend but Sukuk shows higher fall in the yields as compared to the Bonds and T-Bill yield and GDP shows a growing trend. But currently the SBP's basis is $10.75 \%$. This lag between Sukuk yield and SBP's basis rate brings the risk as the investors shall not buy Sukuk securities which is the risk of Sukuk.

Fig. 5 Yield of Sukuk, Investment Bonds and Treasury Bills

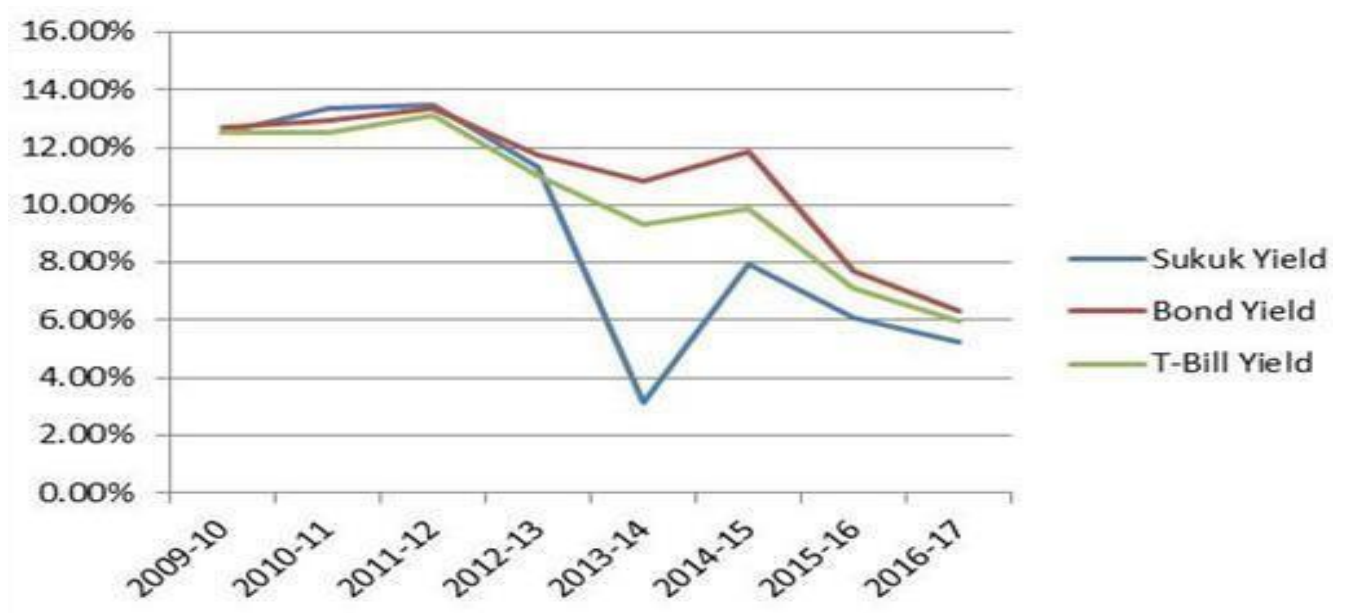

Source: Author's Own Calculations based on GOP data From State Bank of Pakistan (www.sbp.org.pk)

\subsection{Risk exposure of originator}

\subsubsection{Originator: Risk related to repurchase undertaking}

This risk is exposed to the originator who leases an asset for repurchasing or sells the share of business with a repurchase undertaking on a specific date. In the context of Pakistan this risk arises due to volatility of prices of goods in Pakistan because of inflation and devaluation of rupee. 
Fig. 6 Trend in Inflation Indicators in Pakistan

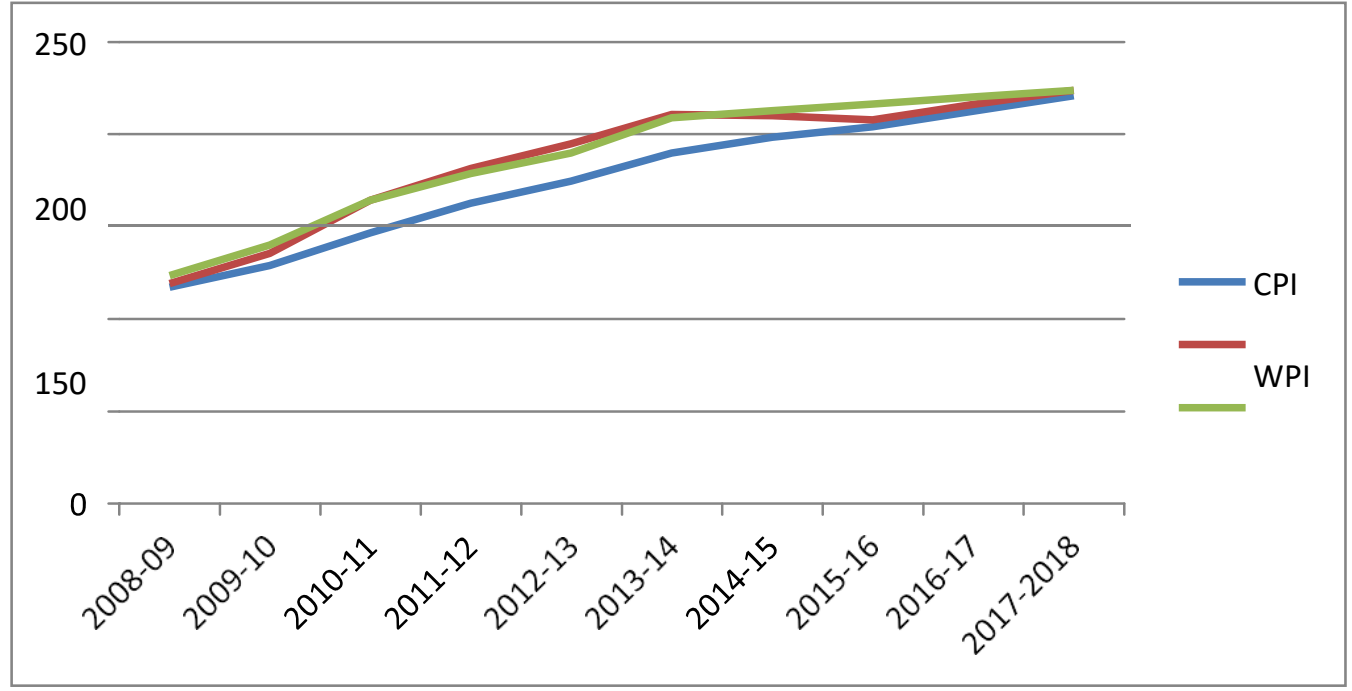

Source: Author's Own Calculations based on GOP data From State Bank of Pakistan (www.sbp.org.pk)

\begin{tabular}{|l|l|l|l|l|l|l|l|r|r|}
\hline Years & $2009-10$ & $2010-11$ & $2011-$ & $2012-$ & $2013-$ & $2014-$ & $2015-$ & 201 \\
\hline GDP growth rate & $3.50 \%$ & $3.62 \%$ & $3.84 \%$ & $3.68 \%$ & $4.05 \%$ & $4.06 \%$ & $4.56 \%$ & 5.5 \\
\hline
\end{tabular}

Table 10Gross Domestic Product (GDP) Growth Rate:

Source: Author's Own Calculations based on GOP data From State Bank of Pakistan (www.sbp.org.pk)

\section{Foreign Exchange (FX) Rates:}

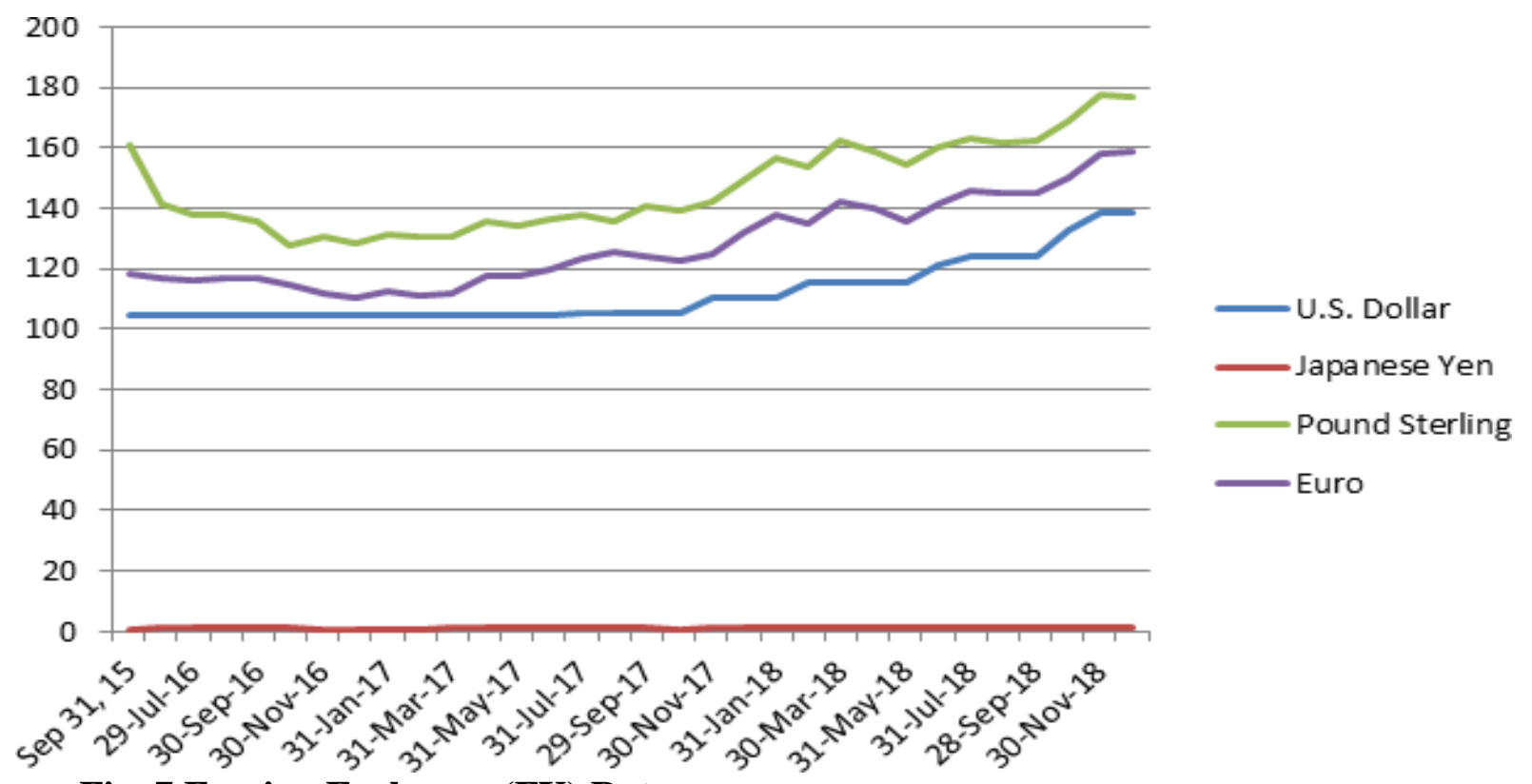

Fig. 7 Foreign Exchange (FX) Rates 
The given statistics show the sharp rise in CPI and a continuous increase in foreign exchange rates however in comparison with these two indicators the GDP growth rate is minimal.

\subsubsection{Servicer exposure to Risk in Pakistan Servicer Default}

A servicer is one who plays his role of an agent on the behalf of issuer and end investors; its obligation is the collection of rental payments or says periodical payments as well as principal.

A credit risk in Sukuk is a long term default risk that rises from the decreasing margin between lending and borrowing. The following table shows that there is decreasing margin between lending and borrowing from 2009 to 2018 that discourages investor to invest in securities.

\subsubsection{Issuer exposure to risks in Context of Pakistan Credit and counterparty Risk}

An issuer is the one who issues Sukuk and the one who is basically in need of finances. So from the issuer side credit risk arises. As all the periodical or say rental payments are to be done by the issuer so this is a major risk that arises from the counterparty issuing Sukuk. If the Sukuk is of Musharaka or Mudaraba then the parties are partners for these reason periodical payments are not fixed so for this scenario the risk arises only at the time of redemption. Yet if it is an Ijara Sukuk then usually the periodical payments are fixed and the issuer is obliged to pay these as well as principal at the time of redemption.

\begin{tabular}{|c|c|c|c|}
\hline \multicolumn{4}{|c|}{ WA Rate (FC Lending and Deposit) } \\
\hline \multicolumn{2}{|c|}{ Lending } & \multicolumn{2}{|c|}{ Deposit } \\
\hline Marginal & Stocks & Marginal & Stocks \\
\hline 5.78 & 5.61 & 2.21 & 1.95 \\
\hline 5.01 & 5.63 & 1.37 & 1.41 \\
\hline 5.26 & 5.51 & 0.93 & 1.03 \\
\hline 3.11 & 4.77 & 1.34 & 0.89 \\
\hline 2.52 & 3.03 & 1.41 & 0.85 \\
\hline 1.80 & 2.90 & 1.25 & 0.70 \\
\hline 2.28 & 3.00 & 1.70 & 0.79 \\
\hline 2.09 & 3.14 & 1.23 & 0.71 \\
\hline 2.86 & 3.00 & 0.88 & 0.57 \\
\hline 3.31 & 2.83 & 2.23 & 0.63 \\
\hline 3.31 & 4.51 & 1.80 & 1.21 \\
\hline
\end{tabular}

TABLE 11 STRUCTURE OF INTEREST RATES

Source: State Bank of Pakistan (www.sbp.org.pk)

\subsection{Default Risk}

If the issuer of the Sukuk ceases to pay its obligation then this Sukuk shall go to default. As the current ratio of issuer party decreases this is an indicator that the issuer may go to default in its periodical obligations and subsequently default on the principal amount. As the most issuances are done in foreign currencies so there is bigger chances of default of delay or non payment of either installments of the principal amount.

\subsection{Sukuk holder (investor) exposure to risk in Pakistan}




\section{Liquidity risk}

From the Sukuk holders perspective the liquidity risk arises majorly in the asset based Sukuk when they become the partner in a venture. So the risk arises when any of the partners withdraws his or her investment from the business and due to withdrawal the liquidity ratio of the issuer decreases and the chances of default are increased (Alswaidan, Daynes, \& Pasgas, 2017).

\section{Coupon Payment Risk}

In the case of Ijara Sukuk (that is asset based Sukuk) the issuer is obliged to pay the coupon payments as stated or promised so the chances of defaults are present for the investor that there may be a delay or non payment of coupon payment is possible in Pakistan. Yet in the asset backed Sukuk case the stricture is less rigid.

\section{Fig 9. Sukuk Yield to Maturity in different countries}

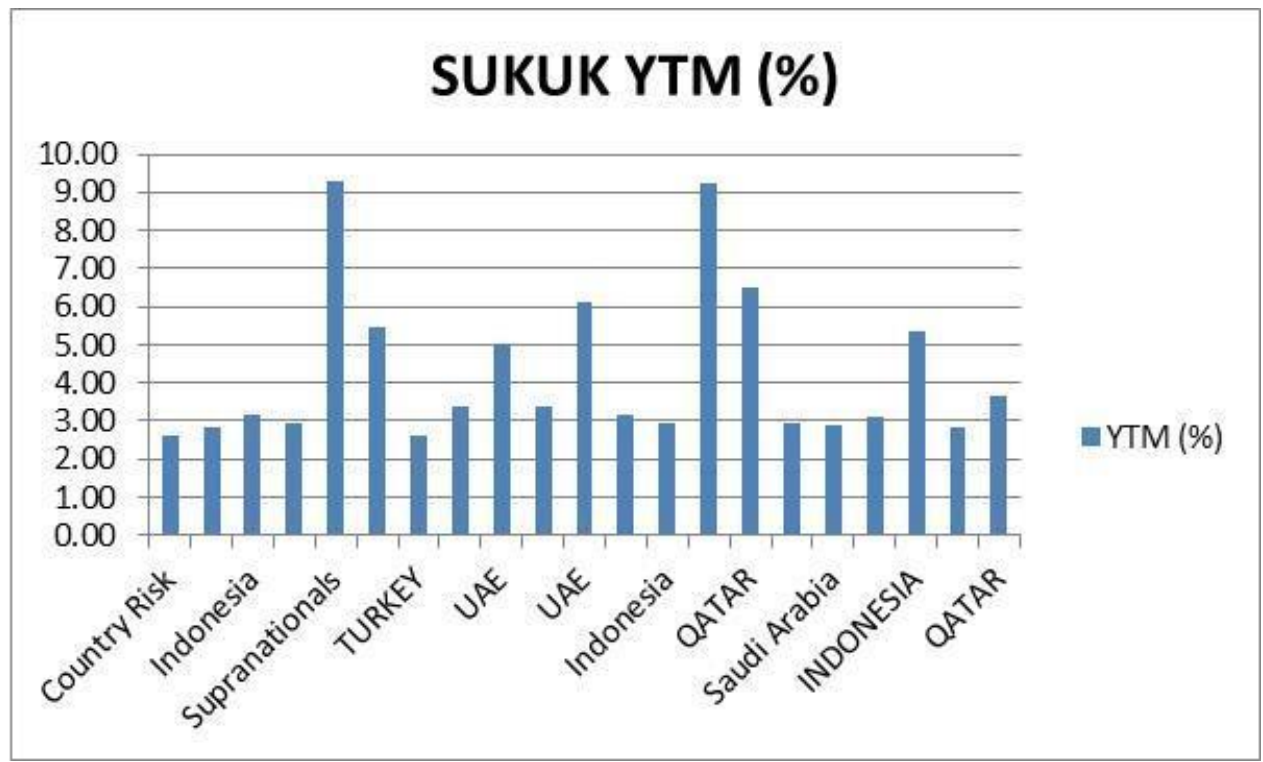

Source: Author's Own Calculations based on GOP data

From State Bank of Pakistan (www.sbp.org.pk)

Fig. 10 Comparative Yield of Sukuk, Investment Bonds and Treasury Bills

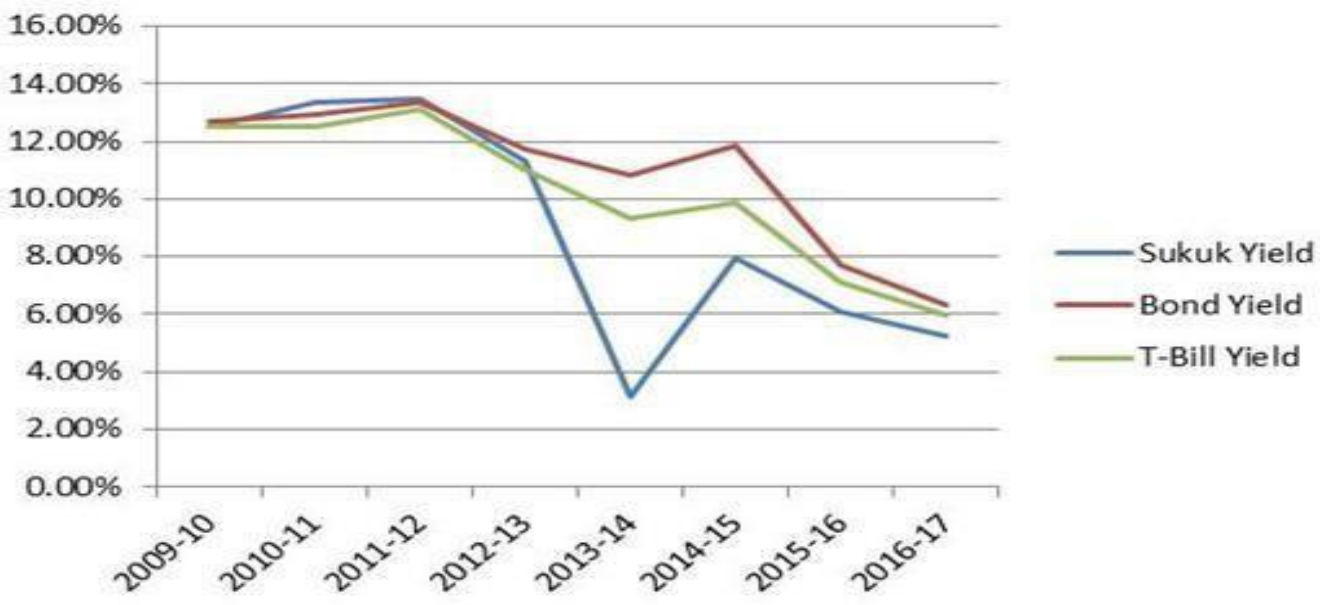




\section{Asset redemption Risk}

The issuer of the Sukuk has to buy back the underlying asset involved in the Sukuk from the Sukuk holders. So there may be a change in the price of underlying asset usually prices of real estate rise and the issuer goes unable to purchase the asset fully (Tariq \& Dar, 2007).

\section{Risk of Rate of Return}

As there is a change in market rate of return there will be a switch in investor's required rate of return and then there shall be two conditions either a investor shall be in state of lose that getting a lesser rate of return as if the structure does not allows to trade that particular Sukuk in the secondary market or they shall sell the Sukuk if it is allowed by the structure to be traded in market.

\section{Impairment of Asset risk}

This risk is constantly available in the asset based Sukuk for the investor in Pakistan, that the asset value decreases as of the states in the book value if issuer. This is basically the reduction of assets market value from the value of it in the books of accounts and Islamic Finance emphasizes that the trade should be done on the real market value of the asset.

\subsection{SPV exposure to risk in Pakistan}

\section{Bankruptcy Risk}

SPV is created in way that it becomes a bankruptcy remote. Through this if there is non payment of the debt then the SPV shall be bankrupted not the issuer company and the asset that has been securitized is not in the danger of loss.

\section{Settlement Risk}

The risk of inability to pay the obligatory amount from one contracting party to the other. So the SPV faces this particular risk if the issuer does not pay its obligatory amount.

\section{Market risk}

Market risk also called a systematic risk, so the Sukuk market also faces the risks from the external factor. Yet this risk is more effective on the fixed income rate risks. As the interest rate of market has been changed the demand for the Sukuk is also shifted. Usually the Sukuk are benchmarked with LIBOR (London inter-bank interest rate) because of which Sukuk are indirectly exposed to market risk(Tariq \& Dar, 2007). Now the Moody's has decreased the rating of Pakistan because of which the risk has risen of Sukuk market.

\section{FX risk}

As the currency rate changes this puts direct and unavoidable effect on the foreign exchange position. Usually the Sukuk are issued in the USD currency if the price of USD declines or the domestic currency or the country rises or vice versa this put effects in the transactions and changes in the value of Sukuk as well as the periodical payments and principal at the time of sale and issuance. There is always a currency mismatch if the Sukuk issuance is done in USD for the home investors and if the issuance is made in domestic currency and the subscriber is from other nationality. 


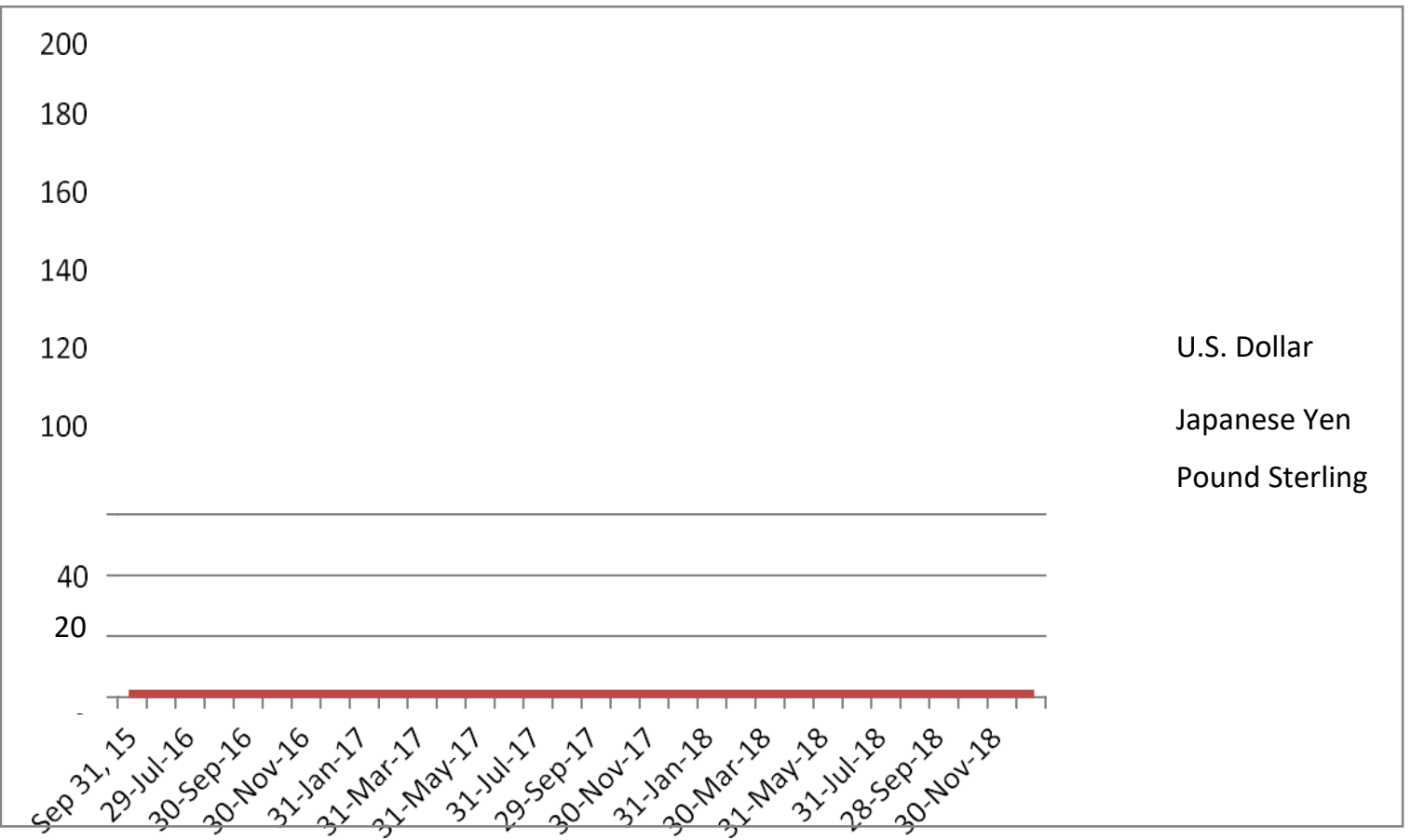

Source: State Bank of Pakistan (www.sbp.org.pk)

\subsection{Tradability Risk}

As Shariah prohibits the loan based types of Sukuk to be traded in the secondary markets. Yet tradability is a property of any asset to be bought or sold in the market. And specifically in the Pakistan there is no secondary market present and there is less supply so the investors hold it until maturity because of which Sukuk certificates are exposed to the this tradability risk(IIFM, 2014).

\subsection{Risk Exposure to Sukuk certificate Price Risk}

The risk of pricing has been inherent in the Sukuk certificates that there is no specific pricing methodology is assigned to Sukuk yet. However for only Ijara Sukuk the pricing methodology is presented by the Naifar \& Mseddi (2013) that concludes that in the pricing methodology term structure of rental property, default probabilities, discount function, recovery rate an rate of return. The changes in price of Sukuk security are due to the reason that how the involved parties and the asset or project have been performing. 


\begin{tabular}{lllll}
\hline w.e.f. & \multicolumn{3}{c}{ Rate of return on } & DS \\
\cline { 2 - 5 } & RICs & DSCs & SSCs & PBA \\
\hline 1-Aug-15 & 8.52 & 9.15 & 7.40 & 11.04 \\
1-Oct-15 & 7.85 & 8.87 & 6.80 & 10.80 \\
1-Dec-15 & 7.54 & 8.68 & 6.40 & 10.56 \\
1-Feb-16 & 7.10 & 8.40 & 6.00 & 10.32 \\
1-Apr-16 & 6.63 & 7.80 & 6.00 & 9.60 \\
1-Jun-16 & 6.55 & 7.70 & 6.00 & 9.60 \\
1-Aug-16 & 6.31 & 7.33 & 5.80 & 9.12 \\
1-Oct-16 & 6.36 & 7.44 & 5.80 & 9.36 \\
1-Feb-17 & 6.54 & 7.54 & 6.00 & 9.36 \\
1-May-18 & 7.63 & 8.10 & 6.60 & 10.08 \\
1-Jul-18 & 8.04 & 8.30 & 6.80 & 10.20 \\
1-Sep-18 & 8.78 & 9.05 & 7.60 & 10.92 \\
1-Nov-18 & 9.72 & 10.03 & 8.60 & 11.88 \\
1-Jan-19 & 12.00 & 12.47 & 11.40 & 14.28 \\
\hline
\end{tabular}

RIC: Regular Income certificate, SSC: Special Saving Cerificate, PBA: Pensioners Benefit Account

\section{Legal risk}

Sukuk have to comply equally with Shariah laws as well as the global laws. In the scenario of Pakistan the State Bank of Pakistan is the regulatory body for the whole country's financial market that includes rules for both conventional finance and Islamic Finance. So, Sukuk have to comply with these laws and rules and regulation.

\section{Shariah compliance risk}

The risk is always there in the Sukuk that and comes from the breach of any involved party's fiduciary responsibilities, in the Shariah compliance respect. There is a clear clause of dissolution of Sukuk in the Sukuk prospectus if there is no compliance done with Shariah.

\section{Conclusion}

In Pakistan the demand of Sukuk by investors exceeds tremendously than the supply of Sukuk. There is least activity of Sukuk in the secondary market in Pakistan so the investors have to hold the Sukuk until its maturity. A significant increase in global as well as in the domestic market of Pakistan specifically since 2010. Emergence of Sukuk has brought momentum in the Islamic Finance and now Islamic Finance comprises 90\% of Sukuk. The reason for vast acceptability of Sukuk is that they come up with 14 types of different structures and options for securitization which serve major needs of investors, issuers and financers. Malaysia is a major player or say contributor in the Islamic finance as well as in the Sukuk market. The first Sukuk was issued by a conventional firm of Malaysia and since it has been a dominating issuer of Sukuk and now it has contributed with a biggest issuance of Green Sukuk to the Sukuk global market for the financing of cleantech or environmental friendly projects. 
5.1 Proposed risk mitigating measures for Sukuk

\begin{tabular}{|c|c|c|c|}
\hline Risk Factors & Applicable & Scale of & Risk \\
\hline Credit Risk & $\begin{array}{c}\text { Yes. In particular, } \\
\text { on rent payment, } \\
\text { fixed rate }\end{array}$ & $\begin{array}{c}\text { Most } \\
\text { Serious }\end{array}$ & Medium \\
\hline Rate of return \\
(Interest rate risk)
\end{tabular}

- As IAAS provides standards in the same way there must be laws and standards for the risk management which are Shariah compliant and being done internationally.

- The Islamic rating agencies should be developed for the rating of Sukuk, asset involved and the issuers creditworthiness according to Shariah principles.

- Audit and strong monitoring of the Sukuk should be done by Islamic finance experts.

- As Malaysia has national Shariah council there must be a Shariah council at international level.

- Asset risk management practices should be implemented.

- The Sukuk structure that is tradable in market should be issued more so that the risk of a party can be hedged.

- To eliminate third party risk a structure must be introduced that can also bring confidence between Sukuk holders and issuers and it has another benefit of cost reduction of third party

- Steps should be taken for the proper documentation and product innovation

- Investment must be done in human resource that is capable of Islamic and conventional finance at the same time 


\section{References}

Ab Majid, H., Shahimi, S., \& Hafizuddin Syah Bangaan Abdullah, M. (2011). Sukuk Defaults and Its Implication: A Case Study of Malaysian Capital Market. 8th International Conference on Islamic Economics and Finance

Afshar, T. A. (2013). Compare and Contrast Sukuk ( Islamic Bonds ) with Conventional Bonds , Are they Compatible? Journal of Global Business Management, 9(1), 4452.

Ahmad, N., Rahim, S. A., \& Sukuk, A. D. (2013). Investigating Post-Crisis

Stock Market Reactions, 1(1). Alsayyed, N., \& Farhan, M. (2010a). Mp r a, (20675), 0-9.

Alsayyed, N., \& Farhan, M. (2010b). Sukukization: Islamic Economic Risk Factors in Shari'ah View. Munich Personal RePEc Archive (MPRA), (20675), 0-9. Retrieved from http://mpra.ub.uni-muenchen.de/20675/

Alswaidan, M. W., Daynes, A., \& Pasgas, P. (2017). Understanding and evaluation of risk in

Sukuk structures. Journal of Islamic Accounting and Business Research, 8(4), 3892015-0021 405.https://doi.org/10.1108/JIABR-05-

Ayub, M. (2018). Securitization, Sukuk and Fund Management Potential to be Realized by Securitization, S uk u k and Fund Management Potential to be Realized by Islamic Financial Institutions \#, (November).

Diamer-Bhasha dam Sukuk proposed - Pakistan - DAWN.COM. (n.d.). Retrieved December 6, 2018, from https://www.dawn.com/news/1438504

Dusuki, A. W., \& Mokhtar, S. (2010). Critical Appraisal of Shari'ah Issues on Ownership in Asset-Based Sukuk As Implemented in The Islamic Debt Market. Isra Research Paper, 8.

Hamid, N. H. A., Zakaria, N. B., \& Aziz, N. H. A. (2014). Firms' Performance and Risk with the Presence of Sukuk Rating as Default Risk. Procedia - Social and Behavioral Sciences, 145, 181-188. https://doi.org/10.1016/j.sbspro.2014.06.025

Haron, H. (2012). Rating Approach To Sukuk: A MARC Perspective. Ratings Research, Malaysian Rating Corporation B Erhad, 1-14.

Hussain, M., \& Turk-Ariss, R. (2015). An overview of Islamic finance. IMF Working Paper. https://doi.org/10.5089/9781513590745.001

INTERNATIONAL ISLAMIC FINANCIAL MARKET (IIFM). (2014). IIFM Sukuk Report (4nd Edition) A Comprehensive Study of the Global Sukuk Market, (November), 136. https://doi.org/10.1007/s13398-014- 0173-7.2

Jakhura, B. (2016). The Implementation of Islamic Finance Bonds (Sukuk) in South Africa: An Analysis of the Inaugural South African Sovereign Usufruct Based Sukuk, (December), 1-81.

Junaid, H. M. A. (2010). Islamic capital market: Sukuk and its risk management in current screnario. 
Kamarudin, M. F., Kamaluddin, N., Manan, S. K. A., \& Ghani, G. M. (2014a). Defaulters Profile in Malaysia Sukuk Market. Procedia - Social and Behavioral Sciences, 145, 277-285. https://doi.org/10.1016/j.sbspro.2014.06.035

Kamarudin, M. F., Kamaluddin, N., Manan, S. K. A., \& Ghani, G. M. (2014b). Defaulters Profile in Malaysia Sukuk Market. Procedia - Social and Behavioral Sciences, 145, 277-285. https://doi.org/10.1016/J.SBSPRO.2014.06.035

Market, G. S. (2018). Iifm Sukuk Report, (April).

Minhat, M., \& Dzolkarnaini, N. (2017). Which firms use Islamic financing? Economics Letters, 150(May 2011), 15-17. https://doi.org/10.1016/j.econlet.2016.10.036

Mohammed Imad Ali, I. R. F. (n.d.). Islamic Banking and Finance: Principles and Practices. Marifa's.

Mohd Sam, M. F., Tahir, M. N. H., Rajiani, I., \& Muslan, N. (2011). Green Technology Compliance in Malaysia for Sustainable Business. Journal of Global Management, 2(1), 5565. https://doi.org/10.2500/aap.2009.30.3201

MUHAMMAD AL-AMINE, M. A.-B. M. (2010). SUKUK MARKET: INNOVATIONS AND CHALLENGES. Applied Financial Economics, 20(21), 1615-1625.

https://doi.org/10.1080/09603107.2010.522519

Naifar, N., \& Mseddi, S. (2013). Sukuk spreads determinants and pricing model methodology. Afro-Asian J. of Finance and Accounting, 3(3), 241. https://doi.org/10.1504/AAJFA.2013.054425

Pegah Zolfaghari. (2017). An Introduction to Islamic Securities (Sukuk), 2, 1-42.

https://doi.org/10.1109/68.841264 Raei, F., \& Cakir, S. (2007). Sukuk vs. Eurobonds: Is

there a Difference in Value-At-Risk? IMF Working Papers, 07(237), 1. https://doi.org/10.5089/9781451868012.001

Rezaei, Z. (2013). Sukuk: An Islamic Financial Instrument. Management and Administrative Sciences Review, ISSN(3), 2308-1368. Retrieved from

S.R. Vishwanath, S. A. (2009). An Overview of Islamic.

SPVs in Asset Securitization - Wilmington Trust. (n.d.). Retrieved February 5, 2019, from https://library.wilmingtontrust.com/z-featureditems/featured-2/theuse-of-spvs-in-asset-securitizations

Sukuk can finance Naya Pakistan Housing Programme - Newspaper - DAWN.COM. (n.d.). Retrieved January 16, 2019, from https://www.dawn.com/news/1457309

Tadajewski, M. (2015). The Dominance Of Asset based Sukuk. Journal of Historical Research in Marketing, 7(4), 486-508. https://doi.org/10.1063/1.2756072

Tariq, A. A., \& Dar, H. (2007). Risks of Sukuk Structures : Implica- tions for Resource Mobilization, 49(April), 203-223. https://doi.org/10.1002/tie

Version, A. (2004). Durham Research Online. Journal of Business Ethics, 44(April), 0-103. https://doi.org/10.1063/1.2756072 


\section{Wajdi Dusuki, A. (2010). CRITICAL APPRAISAL OF SHARI 'AH ISSUES ON OWNERSHIP IN ASSET- BASED SUKUK AS IMPLEMENTED IN THE iSLAMIC DEBT MARKET. ISRA International Journal of Islamic Finance.}

Wijnberge, S. van, \& Zaheer, S. (2013). Sukuk Defaults: On Distress Resolution in Islamic Finance. Tinbergen Institute Discussion Paper, No. 13-087/VI/ DSF57, $1-54$.

Zakaria, N. B., Md Isa, M. A., \& Abidin, R. A. Z. (2012). The Construct of Sukuk, Rating and Default Risk.

Procedia - Social and Behavioral Sciences, 65(ICIBSoS), 662-667.

https://doi.org/10.1016/j.sbspro.2012.11.181 